TARNOWSKIE STUDIA TEOLOGICZNE 36 (2017) NR 2, S. 75-90

http://dx.doi.org/10.15633/tst.2616

ks. Łukasz Plata ${ }^{1}$

KATOLICKI UNIWERSYTET LUBELSKI JANA PAWŁA II

\title{
Rola cudu w apologetyce przed i s soborem watykańskim. Refleksja na podstawie analizy ówczesnych podręczników akademickich
}

U podstaw całego systemu argumentacyjnego tradycyjnej apologetyki leży cud. Teologowie bowiem zawsze twierdzili, że cuda i proroctwa są jakby pieczęcią uwierzytelniającą prawdę słów objawionych ${ }^{2}$.

Pod koniec xıx wieku nastąpiła jednak zmiana klimatu myślowego i rewizja dotychczasowych poglądów na temat cudu. Rozwój nauk o człowieku, biblistyki, nauk teologicznych oraz wzrost klimatu ekumenicznego „zachwiały” dotychczasową apologetyką, w której uzasadnianie faktu Objawienia argumentem z cudu okazało się niewystarczające.

Dlatego w niniejszym artykule zostanie przeprowadzona analiza wybranych podręczników akademickich do apologetyki, jakie pojawiły się przed II soborem watykańskim, aby zbadać, jaką rolę odgrywał w nich „cud” zwłaszcza w odniesieniu do Objawienia.

\section{Cud w nauce I Soboru Watykańskiego}

Pytając o miejsce cudu w apologetyce, trzeba na początku zatrzymać się nad orzeczeniami I Soboru Watykańskiego odnośnie do problematyki cudu, gdyż

1 Ks. mgr lic. Łukasz Plata - kapłan diecezji tarnowskiej, rekolekcjonista, absolwent UPJPII Wydział Teologiczny Sekcja w Tarnowie (2011), licencjat z teologii na tym wydziale (2016), aktualnie doktorant teologii moralnej KUL oraz uczestnik podyplomowych studiów „Szkoła Formatorów” przy Ignatianum w Krakowie. Od 2016 roku członek Stowarzyszenia Teologów Moralistów. Główne kierunki badań: formacja kandydatów do kapłaństwa, dojrzałość uczuciowa, problematyka cudu, Nowa Ewangelizacja, Katolicka Odnowa Charyzmatyczna.

${ }^{2}$ Por. X. Leon-Dufour, Jak mówić dzisiaj o cudach?, „Życie i Myśl” 26 (1976) nr 7/8, s. 26-27. 
te orzeczenia, wprawdzie różnie interpretowane, wywarły znaczny wpływ na akademicki wykład tego zagadnienia.

Apologetyka okresu I soboru watykańskiego traktowała wypowiedzi $\mathrm{Ma}$ gisterium Ecclesiae jako podstawowe wytyczne, które wskazywały drogę apologetom ${ }^{3}$. Soborowe dekrety z 24 kwietnia 1870 roku: o Bogu Stwórcy, o objawieniu, o wierze i rozumie, nie tylko stwierdzają podstawowe prawdy dla apologetyki, ale także bronią praw naturalnego rozumu ludzkiego. Jest w nich mowa m.in. o źródłach wiary, akcie wiary i o cudach, którymi to zagadnieniami sobór po raz pierwszy zajął się w tak obszerny sposób ${ }^{4}$.

W drugim punkcie trzeciego rozdziału konstytucji Dei Filius czytamy: „Niemniej aby nasza wiara była «Posłuszeństwem zgodnym z rozumem» $(\mathrm{Rz} 12,1)$, zechciał Bóg $\mathrm{z}$ wewnętrznymi pomocami Ducha Świętego połączyć zewnętrzne argumenty swojego Objawienia, mianowicie Boskie fakty, a więc przede wszystkim cuda i proroctwa, które znakomicie pokazując wszechmoc i nieskończoną wiedzę Boga, są nader pewnymi i przystosowanymi do umysłowości wszystkich ludzi znakami Bożego Objawienia”' Oprócz tego sobór wyłożył naukę o cudzie w dwóch kanonach, w których ustosunkował się do błędnych interpretacji cudu, jakie wywodziły się z XVIII- i XIX-wiecznego racjonalizmu: „Jeśli ktoś twierdzi, że Objawienie Boże nie może się stać wiarygodne dzięki zewnętrznym znakom i dlatego ku wierze powinno ludzi pociągać własne, wewnętrzne doświadczenie lub prywatne natchnienie - n.b.w." (kan. 3) i: „Jeśli ktoś twierdzi, że cuda są w ogóle niemożliwe stąd wszystkie o nich opowiadania, nawet zawarte w Piśmie Świętym, trzeba uznać za baśnie i mity, albo że cudów nigdy nie można poznać w sposób pewny, ani że na ich podstawie nie da się należycie uzasadnić Bożego pochodzenia chrześcijańskiej religii - n.b.w." (kan. 4) ${ }^{6}$.

Sobór nie dał pełnej nauki o cudzie, jednak przytoczone fragmenty wskazują, że w orzeczeniu tym chodziło o przeciwstawienie się z jednej strony racjonalistom odrzucającym możliwość stwierdzenia w ogóle faktu Objawienia, a z drugiej strony o przeciwstawienie się twierdzeniom protestantów,

3 Por. S. Szydelski, Apologetyka chrześcijańska w ostatnim sześćdziesięcioleciu, „Ateneum Kapłańskie” 42 (1938), s. 330.

${ }^{4}$ Por. S. Szydelski, Apologetyka chrześcijańska w ostatnim sześćdziesięcioleciu, s. 330.

5 Breviarium fidei. Wybór doktrynalnych wypowiedzi Kościoła, oprac. S. Głowa, I. Bieda, Poznań 1988, I 49.

6 Breviarium fidei..., I 56, 57. 
według których rozpoznanie objawienia Bożego jest niemożliwe na drodze rozumowej ${ }^{7}$.

Nauczanie soboru charakteryzuje cud jako kryterium objawienia. Tę charakterystykę cudu można zawrzeć w czterech zasadniczych punktach: (1) cud jest możliwy, (2) cud jest faktem, który wielokrotnie miał miejsce w dziejach objawienia chrześcijańskiego, (3) istnieje możliwość rozpoznawania cudu, (4) przy pomocy cudów można uzasadnić nadprzyrodzoną genezę religii chrześcijańskiej.

Gdy chodzi o możliwość cudu, sobór odwołał się do teologicznej racji, że tylko Bóg i Boża wszechmoc może czynić cuda. Zatem Bóg nie tylko objawił się człowiekowi, ale także udostępnił mu argumenty uzasadniające fakt Objawienia9.

Kolejnym rysem nauczania tego soboru o cudzie jest stwierdzenie, że cuda faktycznie działy się w historii. Ojcowie soboru w trzecim rozdziale Dei Filius wskazywali na liczne zadziwiające fakty, towarzyszące działalności niektórych postaci związanych z Bożym objawieniem. Konstytucja stwierdza, że Mojżeszowi, prorokom, Chrystusowi i apostołom towarzyszyły liczne cuda. Toteż odrzucenie opisów cudów biblijnych jest niezgodne z nauką Kościoła. Ponadto sobór w kanonie 4 poucza, że także inne pozabiblijne relacje o cudach nie mogą być uważane za mity oraz legendy. W ten sposób od strony negatywnej sobór bronił historyczności cudów dziejących się w świecie ${ }^{10}$.

Trzecim zasadniczym elementem soborowej nauki o cudzie jest stwierdzenie, że cuda mogą być rozpoznawane z pewnością i jako takie są pewnymi znakami Objawienia ${ }^{11}$. Kanon 4 nie zawiera żadnych danych na temat przedmiotu rozpoznania oraz pewności jego rozpoznania. Dlatego konstytucja stwierdza, iż rozpoznanie dotyczy przyczyny sprawczej cudu ${ }^{12}$.

Ostatnim elementem soborowej nauki o cudzie jest pogląd stwierdzający, że przy pomocy cudów można uzasadnić nadprzyrodzoną genezę religii chrześcijańskiej. W konstytucji sobór określił, że cud jest „dowodem

7 Por. E. Kopeć, Kryteria wiarygodności objawienia w nauce Soboru Watykańskiego I, w: W. Granat, Z zagadnień kultury chrześcijańskiej, Lublin 1973, s. 38.

${ }^{8}$ Por. E. Kopeć, Kryteria wiarygodności objawienia..., s. 38.

9 Por. M. Rusecki, Cud w myśli chrześcijańskiej, Lublin 1991, s. 272.

${ }_{10}$ Por. M. Rusecki, Traktat o cudzie, Lublin 2006, s. 200-202.

${ }^{11}$ Por. kan. 4 w: Breviarium fidei..., I 57.

${ }^{12}$ Por. E. Kopeć, Kryteria wiarygodności objawienia..., s. 41-43. 
Objawienia” i „najpewniejszym znakiem Objawienia”, natomiast w kanonie 4 potępił poglądy, które odrzucały walor dowodowy cudu.

Sobór widzi więc cud przede wszystkim w funkcji dowodowej czy uzasadniającej oraz określa wysoki walor cudu w funkcji uzasadniania Objawienia, nazywając go najpewniejszym znakiem Objawienia czy jego wiarygodności ${ }^{13}$.

\section{Cud w podręcznikach apologetyki ${ }^{14}$ - analiza}

Zdaniem Stanisława Nagiego pierwszym przedstawicielem nowożytnego nurtu polskiej myśli apologetycznej po I soborze watykańskim był Stefan Pawlicki ${ }^{15}$. W swym dziele O początkach chrześcijaństwa ${ }^{16}$ pod koniec czwartego rozdziału autor zajmuje się pytaniem: Czy cuda są możliwe? Wykazując błędne i niedokładne określenia cudu pochodzące jeszcze z wieku XviII, które widziały w nim czyn przeciwny naturze lub widziały go jako zawieszenie praw natury, Pawlicki przedstawia za św. Tomaszem poprawniejsze określenie cudu jako czynu, sprawionego przez Boga, w sposób przekraczający siły całej natury stworzonej ${ }^{17}$.

Autor zwraca uwagę, że Bóg przez swe działanie ponad siły natury objawia w sposób najwyraźniejszy dla nas swe istnienie i władzę nad światem, toteż stwierdza, „cuda nie tylko są możliwe, lecz nawet konieczne w obecnym stanie ludzkości, aby wierni się wzmacniali, a nawracali niewierni”"18. W tych słowach da się zauważyć ogromną rolę cudu, który miał prowadzić do umocnienia wiary, a niekiedy stawał się nawet dowodem i argumentem wprost prowadzącym do wiary i nawrócenia. Jeszcze wyraźniej jest ona podkreślona w stwierdzeniu: „W istocie jak poseł królewski musi mieć swo-

${ }^{13}$ Por. M. Rusecki, Cud w myśli chrześcijańskiej, s. 278.

${ }^{14}$ Aby odpowiedzieć na pytanie, jaką rolę odgrywał cud w wykładzie podręcznikowym apologetyki, zostanie przeanalizowanych kilka pozycji z polskiej literatury teologicznej, jaka pojawiła się przed II soborem watykańskim. Przy doborze podręczników do apologetyki, zastosowano kryterium chronologiczne, według roku wydania podręczników. Umożliwi to również prześledzenie rozwoju rozumienia cudu w myśli teologicznej.

${ }_{15}$ Por. S. Nagy, Apologetyka polska, w: Dzieje teologii katolickiej w Polsce, red. M. Rechowicz, t. 3, Lublin 1976, s. 195.

${ }^{16}$ S. Pawlicki, O początkach chrześcijaństwa, Kraków 1884.

${ }_{17}$ Por. S. Pawlicki, O początkach chrześcijaństwa, s. 119.

18 S. Pawlicki, O początkach chrześcijaństwa, s. 124. 
je pismo uwierzytelniające, aby mu wierzono, tak posłannik Najwyższego Króla musi z cudem przychodzić, aby uznano w nim misję nadziemską. Cud to kredytyw posłanników Bożych"19. Na podstawie tych słów widać jasno, iż w jego podręczniku cud pełni rolę uwierzytelniającą objawienie.

W apologetyce drugiej połowy XIX wieku pojawiły się tendencje do poszukiwania naukowej odpowiedzi na pytania związane z cudem. Taką postawę ściśle naukowo-przyrodniczą przyjął kanonik Marc-Antoine-François Duilhé de Saint-Projet w podręczniku Apologia naukowa wiary chrześcijańskiej ${ }^{20}$. Główne kryterium wiarygodności Objawienia, jakim jest cud, starał się on opracować w świetle nauk szczegółowych. Z tego stanowiska autor określa cud jako „zjawisko, podpadające pod zmysły, dające się zbadać i sprawdzić, jak każdy fakt doświadczalny, ale niedające się naukowo określić", tzn. odnieść do przyczyny jego bezpośredniej i tą przyczyną go objaśnić. Cud - jak dalej wyjaśnia - z samej swej natury polega na tym, że przewyższa wszelkie znane siły przyrodzone wszechświata; jest i zawsze pozostanie naukowo nieokreślonym, gdyż prawo najwyższe, które nim rządzi, nie podpada pod doświadczenia nauki ${ }^{21}$.

$\mathrm{Na}$ tej samej płaszczyźnie naukowej dowodowy aspekt cudu podkreśla także Adolf Szelążek w swym podręczniku Nauki apologetyczne zastosowane do potrzeb i wymagań duchowych inteligencyi $i^{22}$. Mówiąc o cudach, jak sam stwierdza: „Żadnych dysput w tym przedmiocie nie będziemy rozpoczynali. Posłuchamy tylko, co mówi nauka; ona wyrokować będzie"23. Autor stwierdza, że jeżeli jakieś zjawisko przekracza zakres wszystkich sił natury stworzonej, to mamy pełne pojęcie cudu, zgodne $\mathrm{z}$ tym, co podaje św. Tomasz. Jest to określenie teologiczne, jednak niesprzeciwiające się nauce $^{24}$. Szelążek zauważa w kontekście trudności związanych z cudami,

19 S. Pawlicki, O początkach chrześcijaństwa, s. 123.

${ }^{20}$ Kanonik M. A. F. Duilhé de Saint-Projet, Apologia naukowa wiary chrześcijańskiej, przeł. bp H. P. Kossowski, Warszawa 1894.

${ }^{21}$ Por. Kanonik M. A. F. Duilhé de Saint-Projet, Apologia naukowa wiary chrześcijańskiej, S. $149-150$.

${ }^{22}$ A. Szelążek, Nauki apologetyczne zastosowane do potrzeb $i$ wymagań duchowych inteligencyi, Warszawa 1901.

${ }_{23}$ A. Szelążek, Nauki apologetyczne..., s. 102. Autor przytacza zdobycze nauki, które w kilku punktach uczony Ernest Naville, członek korespondent Instytutu Filozoficznego, zawarł w dziele O fizyce nowożytnej.

${ }^{24}$ Por. A. Szelążek, Nauki apologetyczne..., s. 104. 
że rozwój nauk „umacnia coraz bardziej siłę dowodową cudów; ułatwia zadanie Kościoła w stwierdzeniu ich rzeczywistości. Wszystkie odkrycia naukowe od początku świata nie zdołały obalić ani jednego z tych cudów, które mamy zapisane w księgach Pisma Świętego"25.

Jak zauważa Marian Rusecki, ze znaku Bożego próbowano uczynić argument niemal przyrodniczy, jednak tak formułowana argumentacja przybierała często postać pseudonaukową. Apologetycy wchodzili bowiem nie na swój teren i gubili aspekt religijny cudu, który go wiąże z objawieniem Bożym ${ }^{26}$.

W tym samym czasie wśród autorów katolickich zaczęli się pojawiać teologowie, którzy w kryteriologii Objawienia zaczęli uwzględniać obok kryteriów zewnętrznych kryteria wewnętrzne. W kręgu polskiej literatury teologicznej takie stanowisko prezentuje Aleksander Pechnik w podręczniku Zarys apologetyki $i^{27}$.

Pechnik stwierdza, że „są pewne znamiona charakterystyczne, po których poznajemy Objawienie Boże i odróżniamy je od objawień rzekomych [...]. Znaki te dzielą się na wewnętrzne i zewnętrzne" ${ }^{28}$. Autor, odwołując się do nauki I Soboru Watykańskiego, umiejscawia cud wraz z proroctwami wśród zewnętrznych znaków, po których można rozpoznać Objawienie prawdziwe ${ }^{29}$. Określając cud, przywołuje definicję św. Tomasza z Akwinu oraz dokonane przez niego rozróżnienie cudów. Przez cud autor rozumie „czyn, dokonany w świecie zmysłowym, czyn, który nie da się wyjaśnić działaniem sił naturalnych i stanowi wyjątek od zwyczajnego porządku" ${ }^{30}$ i dalej dodaje: „Wszelako sam Bóg może, jako Stwórca i Pan wszechświata, sprawić w pewnych wypadkach, że zjawiska odbywają się w sposób niezgodny z prawami przyrody. Każdy cud Jego jest dziełem, a mianowicie «bezpośredniem», jeżeli On sam działa, nie posługując się żadnem stworzeniem - a "pośredniem», jeżeli używa do tego Aniołów lub ludzi, którzy wówczas są Jego narzędziami”" ${ }^{1}$.

${ }^{25}$ A. Szelążek, Nauki apologetyczne..., s. 105.

${ }^{26}$ Por. M. Rusecki, Traktat o cudzie, s. 191.

${ }^{27}$ A. Pechnik, Zarys apologetyki, Lwów 1901.

${ }^{28}$ A. Pechnik, Zarys apologetyki, s. 58.

${ }^{29}$ Por. A. Pechnik, Zarys apologetyki, s. 58.

${ }^{30}$ A. Pechnik, Zarys apologetyki, s. 59.

${ }^{31}$ A. Pechnik, Zarys apologetyki, s. 59. 
Tak więc siła dowodowa cudu wynika z samej jego istoty, gdyż jego bezpośrednią przyczyną sprawczą jest Bóg. Opiera się ona także na związku $\mathrm{z}$ Objawieniem, które miał potwierdzaćc ${ }^{32}$. Widać więc w tym podręczniku kolejny przykład spojrzenia na cud w kategoriach dowodowych, jako na zewnętrzny znak w stosunku do Objawienia.

Pewne novum w określeniu cudu na tle ówczesnych autorów prezentuje Marcin Giemza w podręczniku Zbiór wykładów apologetycznych wydanym pod redakcją Tadeusza Trzcińskiego ${ }^{33}$. Autor, odpowiadając na pytanie, co to jest cud, stwierdza, że "jest to nadzwyczajne zdarzenie w świecie widzialnym, które nie da się wytłumaczyć siłami działającymi w naturze, lecz swą przyczynę ma w Bogu i służy do celu nadnaturalnego Boskiego"34.

Według niego dla poszczególnych osób cud może być skutecznym środkiem prowadzącym do wiary. „Cud winien być pojęty jako środek, przez który Objawienie staje się naszym udziałem. Obok wszechwiedzy Boskiej, objawia się tu Boska wszechmoc i potęga. Cud ma za cel prowadzić do Boga i do boskości, umacniać w wierze i budzić życie moralne" ${ }^{35}$. Cuda - jak stwierdza Giemza - „wprawdzie nie mogą wiary wymusić, ale do niej prowadzą, wzbudzają cześć dla religii jedynego Boga, który do żywota wiecznego prowadzi”"36.

Podręcznik ten prezentuje zatem nieco szersze spojrzenie na zagadnienie cudu, ukazujące jego funkcję motywacyjną w odniesieniu do wiary chrześcijańskiej. Jak zauważa Rusecki na początku xx wieku takie ujęcie było dość powszechne ${ }^{37}$.

Kolejny podręcznik Apologetyka, czyli dogmatyka fundamentalna autorstwa Macieja Sieniatyckiego jest przykładem sumarycznego, samodzielnie skonstruowanego wykładu podstawowej problematyki apologetycznej, $\mathrm{w}$ tym nauki o cudzi ${ }^{38}$. Wykład na temat cudu autor umiejscawia w rozdziale drugim zatytułowanym O objawieniu w ogólności. Cud jako „fakt

${ }^{32}$ Por. M. Rusecki, Cud w myśli chrześcijańskiej, s. 256.

${ }_{33}$ M. Giemza, Co to jest cud?, w: Zbiór wykładów apologetycznych, red. T. Trzciński, Poznań 1912.

${ }^{34}$ M. Giemza, Co to jest cud?, s. 50.

${ }^{35}$ M. Giemza, Co to jest cud?, s. 50.

${ }^{36}$ M. Giemza, Co to jest cud?, s. 50.

${ }_{37}$ Por. M. Rusecki, Wierzcie moim dziełom. Funkcja motywacyjna cudu w teologii Xx w., Katowice 1988, s. 226.

$3^{8}$ Por. M. Sieniatycki, Apologetyka, czyli dogmatyka fundamentalna, Kraków 1932. 
(zjawisko, skutek) pod zmysły podpadający, nadzwyczajny, przewyższający siły całego stworzenia, przez Boga samego tylko zdziałany" ${ }^{39}$ znajduje się wśród kryteriów zewnętrznych Objawienia, co świadczy, że Sieniatycki, idąc za nauczaniem I Soboru Watykańskiego, przypisuje mu dużą wartość dowodową ${ }^{40}$. Autor stawia tezę, że „cuda na potwierdzenie danej prawdy lub religii, jako objawionej, zdziałane, są niezbitym dowodem objawienia tej prawdy lub religii" ${ }^{41}$. Następnie precyzuje, że aby cud był dowodem, iż pewna nauka jest objawiona, trzeba, aby był bezpośrednio lub pośrednio uczyniony na stwierdzenie objawienia tej prawdy. Bo tak jak pieczęć królewska wtedy tylko autentyczność dokumentu stwierdza, gdy jest pod nim wyciśnięta, tak i cud, choćby prawdziwy, nie potwierdza danej nauki jako Bożej, jeśli się nie stał na jej potwierdzenie ${ }^{42}$. „Cuda prawdziwe może czynić tylko Bóg, lub z Jego rozkazu i Jego mocą istota rozumna, anioł lub człowiek. Jeśli tedy Bóg czyni cud na potwierdzenie, iż nauka od niego pochodzi, cud jest wtedy jakby pieczęcią bożą, jest jakby podpisem bożym, gwarantującym prawdziwość i objawienie danej nauki”33.

I w tym podręczniku widać więc spojrzenie na cud jako na kryterium wiarygodności objawienia Bożego, a nawet jako jego dowód.

Przykładem takiego spojrzenia na cud jest także koncepcja pojawiająca się w Apologetyce (Wstęp do teologii) Władysława Rosłana ${ }^{44}$. Podręcznik ten nie stanowi systematycznego wykładu, lecz jest to szereg odpowiedzi na pytania z zakresu apologetyki, dlatego nie ma osobnego paragrafu poświęconego zagadnieniu cudu. Zagadnienie to pojawia się dopiero w związku z pytaniem znajdującym się w drugim rozdziale: W jaki sposób można stwierdzić fakt objawienia boskiego? Odpowiadając na to pytanie, autor zauważa, iż „w objawieniu bezpośrednim sam Bóg pozwala poznać człowiekowi, że On jest dawcą objawienia” ${ }^{45}$. Natomiast „w objawieniu pośrednim, przekazywanym ludziom przez ludzi, niezbędne są środki, czyli kryteria, pozwalające

39 Por. M. Sieniatycki, Apologetyka..., s. 55.

${ }^{40}$ Por. Ł. Plata, Cud $w$ teologii fundamentalnej i misji Kościoła, Lublin 2015, s. 46.

${ }^{41}$ M. Sieniatycki, Apologetyka..., s. 67.

${ }^{42}$ Por. M. Sieniatycki, Apologetyka..., s. 67.

${ }^{43}$ M. Sieniatycki, Apologetyka..., s. 67.

${ }^{44}$ W. Rosłan, Apologetyka (Wstęp do teologii). Dla prywatnego użytku słuchaczy Instytutu Wyższej Kultury Religijnej w Warszawie, Warszawa 1938.

${ }^{45}$ W. Rosłan, Apologetyka (Wstęp do teologii)..., s. 45. 
z pewnością rozpoznać boskie pochodzenie głoszonej przez ludzi nauki” ${ }^{46}$. Takim kryterium są cuda, i należą one do kryteriów zewnętrznych, gdyż są to pewne znaki zewnętrznie złączone $\mathrm{z}$ religią objawioną.

Autor, idąc po linii nauczania soboru, określa cud jako „fakt (zjawisko, znak nadprzyrodzony) podpadający pod zmysły, zdziałany przez Boga w świecie" ${ }^{47}$. I jeżeli został on zdziałany na potwierdzenie, że dana nauka pochodzi od Boga, to jest niewątpliwym kryterium prawdziwości tej nauki.

Kolejnym podręcznikiem poruszającym problematykę cudu i jego roli jest Apologetyka podręczna Stanisława Bartynowskiego ${ }^{48}$. W podręczniku tym zagadnienie cudu znajduje się w części zatytułowanej O religii objawionej w ogólności w rozdziale pierwszym o tytule Możliwość religii objawionej ${ }^{49}$.

Autor, mówiąc o cudach i proroctwach jako znamionach wiarygodnego Objawienia, wyjaśnia, iż Bóg, dając ludziom Objawienie, chce tym samym, aby je przyjęli. W tym też celu nadał religii, przez siebie objawionej, pewne znamiona, przy pomocy których łatwo można poznać, że pochodzi ona od Niego ${ }^{50}$. Dlatego kiedy znamiona wewnętrzne wskazują, że jakaś prawda może być objawiona, to zewnętrzne udowadniają niezbicie, że w istocie została objawiona ${ }^{51}$. Muszą zatem istnieć tego rodzaju znaki stwierdzające Boskie pochodzenie religii, które przewyższają wszelkie siły natury stworzonej - a tymi są cuda i proroctwa ${ }^{52}$.

Bartynowski nie zamieszcza w swym podręczniku ścisłej definicji cudu, natomiast w sposób opisowy wyjaśnia jego istotę. Zwraca uwagę, że „istota cudu wymaga, aby był zjawiskiem «niezwykłym», podpadającym pod zmysły, przeto łatwo «dostrzegalnym», a nadto stosunkowo «rzadkim», gdyż inaczej nie zwracałby uwagi ludzkiej, a tym samym nie mógłby służyć do celów wyższych, np. do stwierdzenia objawionej prawdy"53. Nie jest to pełne wyjaśnienie istoty cudu, gdyż cała jego moc dowodowa opiera się na jednym

${ }^{46}$ W. Rosłan, Apologetyka (Wstęp do teologii)..., s. 45.

47 W. Rosłan, Apologetyka (Wstęp do teologii)..., s. 48.

${ }^{48}$ S. Bartynowski, Apologetyka podręczna, Warszawa 1948. Apologetyka podręczna została po raz pierwszy wydana w Krakowie w roku 1911. Łącznie ukazało się kilkadziesiąt tysięcy egzemplarzy dzieła. W niniejszej pracy posłużę się wydaniem ósmym z roku 1948.

${ }^{49}$ Por. S. Bartynowski, Apologetyka podręczna, s. 175-215.

${ }^{50}$ Por. S. Bartynowski, Apologetyka podręczna, s. 177.

${ }^{51}$ Por. S. Bartynowski, Apologetyka podręczna, s. 178.

${ }_{52}$ Por. S. Bartynowski, Apologetyka podręczna, s. 180.

53 S. Bartynowski, Apologetyka podręczna, s. 180. 
szczególe, który wyróżnia go od każdego naturalnego zjawiska. Pisze autor, że „najważniejszą cechą każdego cudu jest to, że przewyższa siły natury stworzonej i dlatego w żaden sposób nie może być wywołany wyłącznie samymi siłami przyrody, ale wymaga bezpośredniego wkroczenia Boga w porządek natury” ${ }^{54}$. „Każdy cud Boży ma zawsze dobro wyższe na celu, bo jest wyjątkiem od prawa przyrody, zdziałanym dla dobra moralnego" 55 . Tym dobrem moralnym jest albo objawienie woli Bożej, albo potwierdzenie Boskiej nauki, albo udowodnienie czyjejś świętości, aby ją dać za wzór do naśladowania, albo w ogóle uświęcenie duszy człowieka.

Dla Bartynowskiego cud jest jednym z motywów wiarygodności Objawienia, który nie prowadzi nas do wiary w sposób apodyktyczny, ale nas do aktu wiary usposabia, i na tym polega jego apologetyczne zadanie ${ }^{56}$. Spełnia on rolę pomocniczą, gdyż obok cudu w osądzie wiarygodności bierze także udział wolna wola człowieka. Cud jest jednym ze środków prowadzących do wiary, który „nie tylko nie uwłacza mądrości Bożej i nie sprzeciwia się wcale powszechnemu planowi Bożemu w wszechświecie, ale owszem staje się bardzo odpowiednim środkiem do jego przeprowadzenia"57.

Ostatnia pozycja $\mathrm{z}$ omawianego okresu to ukazująca się tuż przed II soborem watykańskim Apologetyka totalna Wincentego Kwiatkowskiego ${ }^{58}$.

Mimo iż apologetyk z Warszawy żył i tworzył jeszcze przed Vaticanum II, to jego spojrzenie na zagadnienie cudu jest wyrazem pewnej intuicji, która kierowała go w stronę posoborowej koncepcji cudu jako znaku. Intuicja ta wyraża się w dostrzeżeniu związku cudu ze słowem ${ }^{59}$.

Kwiatkowski widzi konieczność ścisłej integracji słów oraz czynów Jezusa. Ten związek cudu ze słowem zauważa przy omawianiu cudów Mistrza z Nazaretu - Jezus, w odróżnieniu od innych cudotwórców, własnym słowem - a nie za pomocą magicznych gestów - powodował ich zaistnienie, a nawet je objaśniał ${ }^{60}$.

W rozdziale drugim w paragrafie zatytułowanym Dynamiczna świadomość Jezusa w ogólności autor, zajmując się cudami Pana Jezusa, stwierdza,

\footnotetext{
${ }^{54}$ S. Bartynowski, Apologetyka podręczna, s. 181.

55 S. Bartynowski, Apologetyka podręczna, s. 185.

${ }^{56}$ Por. S. Bartynowski, Apologetyka podręczna, s. 185.

57 S. Bartynowski, Apologetyka podręczna, s. 185.

${ }_{58}$ W. Kwiatkowski, Apologetyka totalna, t. 2, Warszawa 1962.

59 Por. Ł. Plata, Cud $w$ teologii fundamentalnej..., s. 49.

${ }^{60}$ Por. Ł. Plata, Cud $w$ teologii fundamentalnej..., s. 49.
} 
że „obraz Jezusa - nauczyciela bez cudów byłby podobny do obrazu poety bez poezji lub wodza bez zwycięstwa, czyli z punktu widzenia historyczno-krytycznego byłby bardzo problematyczny, ponieważ nie pochodziłby z tradycji najstarszej, lecz z tradycji późniejszej gminy chrześcijańskiej" ${ }^{\prime 1}$.

Apologetyk z Warszawy podkreśla, że w źródłach biblijnych nie da się przeprowadzić ścisłej linii demarkacyjnej między Jezusowymi logiami a ergami, „które w świetle samych wypowiedzi Jezusa są wyrazem Jego świadomości motywacyjnej" ${ }^{62}$. Obraz Jezusa - Nauczyciela bez cudów naruszałby paralelę, jaka niewątpliwie zachodzi między Jego wypowiedziami i czynami ${ }^{63}$.

Toteż w świetle historyczno-filologicznym na tle pism Nowego Testamentu autor określa pojęcie cudu biblijnego „jako zjawiska (widzialnego) niezwykłego, zdziałanego w dziedzinie duchowej czy materialnej szczególną mocą Boga i za Jego interwencją w celu motywacyjno-soterycznym" ${ }^{64}$.

Autor, omawiając problematykę cudu, przytacza psychologiczne cudu ujęcie św. Augustyna i ujęcie obiektywne św. Tomasza z Akwinu, gdyż - jak twierdzi - obydwa te ujęcia nie wykluczają się, lecz wzajemnie uzupełniają, stanowiąc w harmonijnej syntezie pełną ideę cudu w katolickiej literaturze teologicznej ${ }^{65}$.

\section{Cud w podręcznikowym wykładzie apologetyki - synteza}

W oparciu o doktrynę I Soboru Watykańskiego na temat wiary, cudu i roli rozumu w poznaniu religijnym ukształtował się pogląd na metodologiczny status apologetyki, który za Nagym można streścić w czterech następujących punktach:

1. apologetyka przynależy do kręgu dyscyplin teologicznych, ale jest dyscypliną sui iuris zarówno ze względu na cel, jak i metodę, jaką się posługuje,

2. główne zadanie apologetyki to: a) racjonalne usprawiedliwienie postawy wiary akceptującej objawienie chrześcijańskie jako w pełni wiarygodne, b) określenie principiów leżących u podstaw rozumowania teologicznego i c) skuteczne przeciwstawianie się opozycji racjonalistyczno-innowierczej,

${ }^{61}$ W. Kwiatkowski, Apologetyka totalna, s. 175-177.

${ }^{62}$ W. Kwiatkowski, Przedmiot apologetyki naukowej, „Collectanea Theologica” 30 (1959), s. $10-19$.

${ }^{63}$ Por. W. Kwiatkowski, Apologetyka totalna, s. 176.

${ }^{64}$ W. Kwiatkowski, Apologetyka totalna, s. 176.

${ }^{65}$ Por. W. Kwiatkowski, Apologetyka totalna, s. 509-528. 
3. apologetyka osiąga cele swoje na drodze racjonalnej (a nie teologicznej) analizy rzeczywistości cudów i proroctw Chrystusowych, historycznej analizy faktów eklezjologicznych i znamion Kościoła, co czyni z niej dyscyplinę o charakterze na wskroś obiektywnym i historycznym,

4. tak pojęta apologetyka jest nauką kościelną, bo prócz tego, że służy Kościołowi, swoje wywody prowadzi pod okiem Kościoła ${ }^{66}$.

Taki schemat wykładu apologetycznego, mimo iż stale i nieraz gwałtownie atakowany jako teoretyczny status apologetyki, stosowany był w praktyce i on też inspirował sporą jak na tamte czasy liczbę podręczników apologetyki, i co za tym idzie uniwersytecko-seminaryjne wykłady tego przedmiotu ${ }^{67}$.

Po analizie kilku dawniejszych podręczników można zauważyć, że w dawniejszej apologetyce patrzono na cud często jako na kryterium wiarygodności Objawienia, co podkreślało jego obiektywny i przedmiotowy charakter. Cud jako kryterium traktowano zwykle w kategoriach rzeczowych, apersonalnych i ahistorycznych, podobnie jak i objawienie Boż $e^{68}$. Przyjmowano, że cuda dzieją się jedynie w chrześcijaństwie katolickim i dlatego dowodzą w sposób wyjątkowy jego boskiego pochodzenia ${ }^{69}$. One to uwiarygadniają wobec ludzi Bożych posłanników, a tym samym dowodzą boskiego pochodzenia religii.

Można też dostrzec, że w podręcznikach apologetyki do czasów II soboru watykańskiego dominowała zasadniczo koncepcja obiektywistyczna. Została ona przyjęta w nauce Vaticanum I i zasadniczo obowiązywała do lat 40. $\mathrm{xx}_{\text {wieku }}{ }^{\mathrm{o}}$. Było to spowodowane tym, że zdecydowana większość przytoczonych autorów widziała w nauce I Soboru Watykańskiego tomistyczną doktrynę na temat cudu, tylko nieco zmodyfikowaną.

Koncepcja obiektywistyczna zacieśniała funkcję cudu niemalże wyłącznie do roli - zewnętrznego w stosunku do Objawienia - dowodu, służącego jako pieczęć potwierdzająca jego prawdziwość i wiarygodność. Z czasem doprowadziło to do coraz to większej absolutyzacji wartości dowodowej cudu, tak iż zaczęto traktować go jako argument niejako wymuszający wiarę

${ }^{66}$ Por. S. Nagy, Apologetyka czy teologia fundamentalna, „Roczniki Teologiczno-Kanoniczne" 19 (1972), s. 116.

${ }^{67}$ Por. S. Nagy, Apologetyka czy teologia fundamentalna, s. 116.

${ }^{68}$ Por. M. Rusecki, Wierzcie moim dziełom..., s. 40.

${ }^{69}$ Por. M. Rusecki, Wierzcie moim dziełom..., s. 222.

$7^{\circ}$ Por. K. Panasiuk, Ewolucja pojęcia cudu we współczesnej teologii fundamentalnej, „Studia Bydgoskie" 2 (2008), s. 54. 
w Boga. Drugą konsekwencją powyższego rozumienia cudu było także to, że cud wyizolowany i wyłączony z kategorii Objawienia, zatracił tym samym swój właściwy kontekst, tzn. kontekst religijny, w którym winien być odczytywany ${ }^{71}$.

Scholastyczna koncepcja cudu przedostała się do podręczników akademickich i seminaryjnych, a z nich przeszła z kolei do katechizmów. Przez kilka wieków panowała prawie niepodzielnie, formując świadomość wiernych i wytwarzając pewien typ mentalności, w której cud kojarzył się z przekraczaniem natury ${ }^{72}$. W oparciu o nią apologeci traktowali cud niemalże wyłącznie w charakterze dowodu potwierdzającego prawdziwość Objawienia i religii chrześcijańskiej ${ }^{73}$. Ograniczali się zwykle do tradycyjnych argumentów, które miały świadczyć o tym, że cud jest apodyktycznym dowodem nadprzyrodzonego pochodzenia chrześcijaństwa ${ }^{74}$.

Jednak to nie oznacza, że była to postawa wszystkich apologetyków i apologetów katolickich, gdyż refleksje nad cudem, jego naturą i funkcją dowodową przybierały różne formy. Da się zauważyć, że w miarę pojawiania się nowych trudności, zaczęły się pojawiać, paralelnie do formułowanych zarzutów, krótkie odpowiedzi na nie. Problematyka cudu, która nie miała jeszcze zwartego i całościowego wykładu, była wyrażona w pytaniach, a raczej zarzutach, i odpowiedziach na nie. Dopiero późniejsze wypowiedzi na temat cudu zaczęto formułować w sposób bardziej systematyczny ${ }^{75}$.

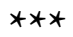

$\mathrm{Z}$ analiz przedstawionych $\mathrm{w}$ niniejszym artykule widać, że sformułowania wypracowane na I soborze watykańskim odnośnie do problematyki cudu znalazły swoje odbicie w wykładzie tego zagadnienia w podręcznikach do apologetyki. Stąd zasadniczo do czasów II soboru watykańskiego w wykładzie podręcznikowym apologetyki dominowała scholastyczna koncepcja cudu, zgodnie z którą rozumiano go jako manifestację przymiotów Boga w przyrodzie oraz dowód zmuszający człowieka do wiary. Takie interpretacje

\footnotetext{
${ }^{71}$ Por. Ł. Plata, Cud $w$ teologii fundamentalnej..., s. 52.

${ }^{72}$ Por. J. Kudasiewicz, Biblia. Historia. Nauka, Kraków 1986, s. 345.

${ }^{73}$ Por. K. Panasiuk, Ewolucja pojęcia cudu..., s. 59.

${ }^{74}$ Por. M. Rusecki, Cud w myśli chrześcijańskiej, s. 253.

75 Por. M. Rusecki, Cud w myśli chrześcijańskiej, s. 258.
} 
cudu szły po linii tradycyjnego nauczania teologiczno-filozoficznego, które zawierało się w tradycji tomistycznej ${ }^{76}$.

Pewnego kroku w kierunku znakowej koncepcji cudu dokonał Kwiatkowski w swej Apologetyce totalnej. Jego analizy poszczególnych pojęć biblijnych, w których wyrażono rzeczywistość cudu, pozwoliły na dostrzeżenie w nim bogactwa treści, które pozwalają uznać, iż cud nie tylko przynależy do objawienia Bożego, ale stanowi jedną z jego form. Tym samym została przesunięta funkcja motywacyjna cudu $z$ zewnątrz do wnętrza Objawienia ${ }^{77}$. Świadczy to o tym, iż jeszcze przed rozpoczęciem II soboru watykańskiego rozpoczęła się stopniowa zmiana zarówno pojęcia cudu, jak i jego funkcji.

\section{Bibliografia}

Bartynowski S., Apologetyka podręczna, Warszawa 1948.

Breviarium fidei. Wybór doktrynalnych wypowiedzi Kościoła, oprac. S. Głowa, I. Bieda, Poznań 1988.

Duilhé de Saint-Projet M. A. F., kanonik, Apologia naukowa wiary chrześcijańskiej, przeł. bp H. P. Kossowski, Warszawa 1894.

Giemza M., Co to jest cud?, w: Zbiór wykładów apologetycznych, red. T. Trzciński, Poznań 1912, s. 49-55.

Kopeć E., Kryteria wiarygodności objawienia w nauce Soboru Watykańskiego I, w: W. Granat, Z zagadnień kultury chrześcijańskiej, Lublin 1973, s. 35-46.

Kwiatkowski W., Apologetyka totalna, t. 2, Warszawa 1962.

Kwiatkowski W., Przedmiot apologetyki naukowej, „Collectanea Theologica” 30 (1959), s. 10-19.

Kudasiewicz J., Biblia. Historia. Nauka, Kraków 1986.

Léon-Dufour X., Jak mówić dzisiaj o cudach?, „Życie i Myśl” 26 (1976) nr 7/8, s. 25-37.

Nagy S., Apologetyka czy teologia fundamentalna, „Roczniki Teologiczno-Kanoniczne" 19 (1972), s. 111-130.

Nagy S., Apologetyka polska, w: Dzieje teologii katolickiej w Polsce, red. M. Rechowicz, t. 3, Lublin 1976, s. 185-215.

${ }^{76}$ Por. M. Rusecki, Cud w myśli chrześcijańskiej, s. 268.

77 Por. Ł. Plata, Cud $w$ teologii fundamentalnej..., s. 52. 
Panasiuk K., Ewolucja pojęcia cudu we współczesnej teologii fundamentalnej, „Studia Bydgoskie" 2 (2008), s. 53-77.

Pawlicki S., O początkach chrześcijaństwa, Kraków 1884.

Pechnik A., Zarys apologetyki, Lwów 1901.

Plata Ł., Cud $w$ teologii fundamentalnej i misji Kościoła, Lublin 2015.

Rosłan W., Apologetyka (Wstęp do teologii). Dla prywatnego użytku słuchaczy

Instytutu Wyższej Kultury Religijnej w Warszawie, Warszawa 1938.

Rusecki M., Cud w myśli chrześcijańskiej, Lublin 1991.

Rusecki M., Traktat o cudzie, Lublin 2006.

Rusecki M., Wierzcie moim dziełom. Funkcja motywacyjna cudu w teologii xx w., Katowice 1988.

Sieniatycki M., Apologetyka, czyli dogmatyka fundamentalna, Kraków 1932.

Szelążek A., Nauki apologetyczne zastosowane do potrzeb i wymagań duchowych inteligencyi, Warszawa 1901.

Szydelski S., Apologetyka chrześcijańska w ostatnim sześćdziesięcioleciu, „Ateneum Kapłańskie" 42 (1938), s. 319-331.

\section{Streszczenie}

W niniejszym artykule autor podjął refleksję nad tym, jaka była rola cudu w wykładzie podręcznikowym apologetyki przed Vaticanum II. Szukając odpowiedzi na to pytanie, najpierw przedstawił nauczanie I Soboru Watykańskiego na temat cudu i jego roli. Następnie poddał analizie kilka polskojęzycznych podręczników akademickich do apologetyki, jakie pojawiły się przed II soborem watykańskim, aby zbadać w nich funkcję cudu w relacji do Objawienia.

\section{Słowa kluczowe}

cud, rola cudu, apologetyka, Objawienie, kryterium Objawienia, analiza

\section{Summary}

The Role of Miracle in Apologetics before The Second Vatican Council. Reflection Based on the Analysis of Academic Textbooks of that Time

In this article, the author made a reflection on the role of miracle in apologetics lecture before The Second Vatican Council. Looking for answers to this question, 
firstly the author presented the teaching of The First Vatican Council on miracle and its role. Then he analyzed several Polish academic textbooks of apologetics that had appeared before The Second Vatican Council in order to examine the function of miracle in relation to the Revelation.

\section{Keywords}

miracle, role of miracle, apologetics, Revelation, Revelation criteria, analysis 